\title{
PENINGKATAN KEMAMPUAN BERHITUNG PEMBAGIAN MELALUI METODE JARIMATIKA PADA SISWA KELAS III SD NEGERI 195 PAGARAN BARU KOTANOPAN
}

\author{
Almira Amir dan Nuraisyah \\ Fakultas Tarbiyah dan Ilmu Keguruan/IAIN Padangsidimpuan \\ almira_stain09@yahoo.com
}

\begin{abstract}
Teachers who are less varied in teaching math can cause students to feel bored and saturated. The usual way teachers use is to memorize or remember the formula, so that burden the students' brains because the ability of each student is different in memorization. Based on the above background, this study aims to determine the extent to which the use of methods can improve the ability of arithmetic numeracy. The division of students in class III SD Negeri 195 Pagaran Baru Kecamatan Kotanopan. The type of research used is Classroom Action Research (PTK). The results showed that in the first cycle there was an increase in students' numeracy skills in the division of material from $47.36 \%$ or 9 students to $61.90 \%$ or 13 students with an increase of $14.54 \%$. Results of reflection on the first cycle, the percentage of learning mastery less than $70 \%$ so that followed in cycle II. In the second cycle there was an increase of $73.68 \%$ or 14 students to $78.95 \%$ or 15 students with an increase of $5.26 \%$. The results of reflection cycle II shows that with the use of the method of Jarimatika, the percentage of learning mastery has reached more than $70 \%$, so there is an increase from cycle I to cycle II of $43.36 \%$. Thus the use of the method of the finger can improve the ability to count The division of the students III SD Negeri 195 Pagaran Baru Kecamatan Kotanopan.
\end{abstract}

Keywords: Jarimatic Method, Ability to Calculate Division.

\begin{abstract}
Abstrak
Guru yang kurang bervariasi dalam mengajarkan matematika dapat mengakibatkan siswa merasa bosan dan jenuh. Cara yang lazim digunakan guru adalah menghafal atau mengingat rumus, sehingga membebani otak siswa karena kemampuan tiap siswa berbeda-beda dalam menghafal. Berdasarkan latar belakang di atas, maka penelitian ini bertujuan untuk mengetahui sejauh mana penggunaan metode jarimatika dapat meningkatkan kemampuan berhitung. Pembagian pada siswa kelas III SD Negeri 195 Pagaran Baru Kecamatan Kotanopan. Jenis penelitian yang digunakan adalah Penelitian Tindakan Kelas (PTK). Hasil penelitian menunjukkan bahwa pada siklus I terdapat peningkatan kemampuan berhitung siswa pada materi Pembagian yaitu dari 47,36\% atau 9 siswa menjadi $61,90 \%$ atau 13 siswa dengan peningkatan sebesar $14,54 \%$. Hasil refleksi pada siklus I, persentase ketuntasan belajar kurang dari $70 \%$ sehingga dilanjutkan pada siklus II. Pada siklus II terjadi peningkatan yaitu dari $73,68 \%$ atau 14 siswa menjadi 78,95\% atau 15 siswa dengan peningkatan sebesar 5,26\%. Hasil refleksi siklus II menunjukkan bahwa dengan penggunaan metode Jarimatika, persentasi ketuntasan belajar sudah mencapai lebih dari $70 \%$ sehingga terjadi peningkatan dari siklus I ke siklus II sebesar 43,36\%. Dengan demikian penggunaan metode jarimatika dapat meningkatkan kemampuan berhitung Pembagian pada siswa III SD Negeri 195 Pagaran Baru Kecamatan Kotanopan.
\end{abstract}

Kata Kunci: Metode Jarimatika, Kemampuan Berhitung Pembagian. 
PENDAHULUAN

$\begin{array}{ccc}\text { Matematika } & \text { merupakan } & \text { ilmu } \\ \text { abstrak, sehingga } & \text { dalam } & \text { proses }\end{array}$ pembelajarannya guru harus mampu membuat suasana yang menyenangkan, dan dapat menarik perhatian peserta didik agar aktif dalam pembelajaran. Setiap peserta didik memiliki karakteristik dan kemampuan yang berbeda, sehingga guru harus merancang metode pembelajaran sesuai dengan materi yang akan diajarkan. Kline dalam bukunya Abdurrahman (2012) bahwa Matematika merupakan bahasa simbolis dan ciri utamanya adalah penggunaan cara bernalar deduktif, tetapi juga merupakan cara bernalar deduktif. Matematika dikenal sebagai ilmu deduktif, artinya bahwa Matematika dimulai dari unsur-unsur yang tidak terdefenisi, aksioma atau postulat dan akhirnya menurunkan teorema dan kebenaran Matematika bersifat universal (Hasratuddin, 2015).

Amri (2013) menyebutkan bahwa pembelajaran adalah upaya menciptakan iklim dan pelayanan terhadap kemampuan, potensi, minat dan kebutuhan peserta didik yang beragam agar terjadi interaksi optimal antara guru dengan siswa serta antara siswa dengan siswa. Matematika merupakan ilmu universal yang mendasari perkembangan teknologi modern yang mempunyai peran penting dalam berbagai disiplin dan memajukan daya pikir manusia.

Di masa depan di perlukan penguasaan matematika yang kuat sejak dini. Untuk itu di perlukan pemahaman yang mendasar tentang fungsi dan tujuan pembelajaran matematika khususnya di sekolah dasar yang akan mendasari perkembangan pemahaman anak terhadap matematika. Dengan demikian dapat di katakan bahwa matematika merupakan pengetahuan yang mempelajari struktur yang abstrak dan pola hubungan yang ada di dalamnya. Ini berarti bahwa belajar matematika pada hakikatnya adalah belajar konsep, struktur konsep dan mencari hubungan atar konsep dan strukturnya.
Susetyawati (2005), bahwa tujuan pembelajaran matematika dipaparkan pada buku standar kompetensi mata pelajaran sebagai berikut:

(a) Melatih cara berfikir dan bernalar dalam menarik kesimpulan, misalnya melalui kegiatan penyelidikan, eksplorasi, eksperimen menunjukkan kesamaan, perbedaan, konsistensi, inkonsistensi.

(b)Mengembangkan aktivitas kreatif yang melibatkan imajinasi, intuisi, dan penemuan dengan mengembangkan pemikiran divergen orisinil, rasa ingin tahu, membuat prediksi dan dugaan, serta mencoba-coba.

(c) Mengembangkan kemampuan dalam me mecahkan masalah.

(d)Mengembangkan kemampuan dalam me nyampaikan informasi atau gagasan antara lain melalui pembicaraan lisan, grafik, peta, diagram.

Hasil observasi awal yang dilakukan di kelas III SD Negeri 195 Pagaran Baru Kecamatan Kotanopan, menunjukkan kemampuan berhitung pembagian siswa masih tergolong rendah. Rendahnya hasil belajar disebabkan karena teknik yang dilakukan dalam pembelajaran dengan menghafal atau mengingat proses dari penyelesaiannya. Tidak semua siswa memiliki daya tangkap yang cepat untuk menghafal cara pembagian, karena daya ingat setiap siswa tidaklah sama.

Mengajarkan Pembagian secara konvensional pada umumnya adalah menggunakan metode drill, bahkan ada yang merupakan kegiatan pemaksaan dengan keharusan menghafal di depan kelas, kebiasaan menghafal sebaiknya dihindarkan sebab akan sia-sia. Pembelajaran bagi siswa diupayakan bermakna dan menyenangkan.

Metode berhitung dengan cara menghafal akan membebani memori otak siswa dan waktu bermainnya tersita untuk menghafal sehinggga siswa malas belajar Matematika dan motivasi siswa untuk belajar Matematika pun menjadi kurang. Salah satu cara untuk metode berhitung yang digunakan agar proses pembelajaran 
PeTeKa (Jurnal Penelitian Tindakan Kelas dan Pengembangan Pembelajaran)

Vol 1 No 1 Tahun 2017 Hal 48-53

menjadi bervariasi adalah dengan menggunakan metode Jarimatika. Metode Jarimatika adalah teknik yang digunakan untuk mempercepat proses berhitung dengan menggunakan fungs jari tangan sebagai alat bantu mengoperasikan operasi hitung baik kali, tambah, kurang. Jarimatika juga bisa disebut kalkulator tangan, kalkulator tangan adalah salah satu cara mengitung menggunakan jari-jari tangan baik Perkalian, Pembagian, Penjumlahan maupun Pengurangan (Kusnadi, 2007).

Menurut Aulia (2008), Jarimatika adalah salah satu metode pembelajaran yang dapat dilakukan oleh guru untuk memudahkan menyampaikan materi pelajaran yang berkaitan dengan operasi hitung baik kali, bagi, kurang serta tambah dan bagi siswa untuk memudahkan melakukan penyelesaian berhitung dengan melibatkan jari-jari pada tangan. Keterlibatan siswa dalam memperagakan metode Jarimatika dapat membuat pelajaran Matematika lebih bermakna. Siswa dapat menggunakan jari-jari tangannya untuk menyelesaikan permasalahan berhitung berdasarkan aturan formasi tangan dan penyelesaian Jarimatika.

Antara nilai formasi jari-jari kanan dan jari-jari kiri memiliki keterkaitan yaitu untuk melanjutkan nilai dari formasi jarijari kanan dilanjutkan dengan formasi jarijari kiri dan untuk hasil terletak pada formasi jari kanan akan tetapi dari formasi jari kanan hasilnya dicocokan dengan nilai di jari kiri.

Sebelum menerapkan metode Jarimatika terlebih dahulu melakukan pemisahan angka, untuk mengetahui angka satuan dari angka puluhan (Jafar, 2012). Pada Jarimatika Pembagian bilangan 36 90 dengan ketentuan yaitu bilangan yang dibagi adalah bilangan satuannya saja sedangkan untuk pembaginya adalah bilangan 6 - 10 dan hasil baginya adalah 6 10. Bila satuan bilangan yag dibagi lebih kecil daripada formasi jari terbuka bilangan pembagi maka satuan bilangan yang dibagi ditambah 10.

Dari uraian di atas, penulis mendeskripsikan hasil Penelitian Tindakan Kelas (PTK) berkolaborasi dengan guru bidang studi Matematika sebagai upaya perbaikan dan peningkatan kualitas pembelajaran pada materi Pembagian di kelas III SD Negeri 195 Pagaran Baru Kecamatan Kotanopan.

\section{METODE}

\section{Jenis Penelitian}

Menurut Arikunto (2010), Penelitian Tindakan Kelas merupakan suatu pencermatan terhadap kegiatan yang sengaja dimunculkan, dan terjadi dalam sebuah kelas. Penelitian tindakan kelas merupakan salah satu upaya yang dapat dilakukan guru untuk meningkatkan kualitas peran dan tanggungjawab guru khususnya dalam pengelolaan pembelajaran. Proses pengkajian masalah pembelajaran dilakukan melalui proses siklus yang meliputi perencanaan, tindakan, pengamatan dan refleksi.

\section{Tempat dan Waktu Penelitian}

Tempat penelitian yang dilakukan di SD Negeri 195 Pagaran Baru yang terletak di Desa Padang Bulan, Muara Soro Kecamatan Kotanopan. Penelitian ini dilaksanakan pada bulan Januari sampai April 2017 pada semester genap tahun ajaran 2016/2017. Materi penelitian adalah operasi hitung bilangan cacah pada pokok bahasan Pembagian. Materi ini diajarkan dengan menggunakan matode pembelajaran Jarimatika.

\section{Subjek Penelitian}

Subjek penelitian ini adalah siswa SD Negeri 195 Pagaran Baru Kecamatan Kotanopan kelas III yang berjumlah 21 siswa. Terdiri dari 14 siswa perempuan dan 7 siswa laki-laki. 


\section{Instrumen Penelitian}

Instrumen pengumpulan data yang peneliti lakukan dalam penelitian ini adalah:

(1)Tes

Bentuk tes yang digunakan dalam penelitian ini adalah tes tertulis dalam bentuk essay (uraian). Tes dalam soal ini merupakan materi Pembagian yang diberikan sebelum dan sesudah mengunakan metode Jarimatika setiap siklusnya. Tes yang diberikan pada soal operasi Pembagian ini sebanyak 5 soal dengan menggunakan metode Jarimatika. Tes tersebut digunakan untuk melihat kemampuan berhitung siswa satelah mengikuti pembelajaran Pembagian.

(2)Observasi

Jenis observasi yang dilakukan dalam penelitian ini adalah observasi langsung. Observasi langsung adalah observasi yang dilakukan oleh pengamat, lembar observasi, lembar observasi untuk siswa yang berisi aktivitas siswa dalam pembelajaran.

\section{Prosedur Penelitian}

Prosedur penelitian tindakan kelas ini terdiri dari 2 siklus, setiap siklus terdiri dari dua kali pertemuan melalui empat tahapan, yaitu perencanaan, tindakan, observasi dan refleksi.

Prosedur yang dilakukan dalam penelitian ini adalah:

\section{(1)Perencanaan}

Pada tahap ini, membuat jadwal pelaksanaan, membuat perangkat pembelajaran seperti RPP serta menyiapkan lembar observasi dan soal tes yang bertujuan untuk melihat bagaimana kemampuan berhitung yang diperoleh siswa.

Tindakan

Tindakan yang dilakukan pada tahap ini adalah penerapan isi rancangan yang dilaksanakan peneliti sesuai dengan RPP yang telah disusun. Guru dan siswa melakukan pembelajaran metode Jarimatika berdasarkan hlm-hlm yang tertuang dalam RPP. Dalam tahap ini dilakukan pemberian tes yang telah disiapkan untuk mengetahui hasil yang dicapai setelah memberikan tindakan.

(2)Observasi

Pada tahap ini observasi dilaksanakan pada saat pembelajaran berlangsung di kelas dengan menggunakan lembar observasi untuk siswa. Observasi dilakukan mulai dari awal sampai akhir pertemuan. Dalam tahap ini guru mata pelajaran Matematika sebagai observer, hanya melakukan pengamatan sesuai dengan lembar observasi siswa yang telah disiapkan. Observer melakukan pengamatan atas dasar apa yang dilihat, dirasakan dan didengar selama kegiatan pembelajaran berlangsung.

(3)Refleksi

Setelah dilaksanakan tindakan dan observasi, maka dalam tahap ini peneliti dan guru menganalisis, menyimpulkan hasil dan dampak yang terjadi dari tindakan yang dilakukan. Refleksi dilakukan bertujuan untuk memperbaiki pelaksaaan tindakan yang dilakukan pada siklus I.

\section{Analisis Data}

Analisis data penelitian ini adalah deduksi data dengan mencari rata-rata siswa dengan teknik persentase. Setelah diperoleh nilai siswa yang mengikuti tes dinyatakan tuntas belajar apabila mendapat nilai $\geq 65$ sesuai dengan standar kelulusan yang telah ditetapkan. Data yang diperoleh dari analisis tes dianalisis untuk melihat ketuntasan belajar siswa.

Rumus nilai rata-rata siswa

$$
\sum=\frac{\sum f i x i}{\sum f i}
$$

Keterangan:

$$
\begin{aligned}
& \bar{X}=\text { nilai rata-rata } \\
& \mathrm{X}_{\mathrm{i}}=\text { data yang ke } \mathrm{i} \\
& f_{i}=\text { frekuensi dari data } \mathrm{X}
\end{aligned}
$$


PeTeKa (Jurnal Penelitian Tindakan Kelas dan Pengembangan Pembelajaran)

Vol 1 No 1 Tahun 2017 Hal 48-53

\section{HASIL DAN PEMBAHASAN}

\section{Hasil Tes}

Tes pada penelitian ini dilakukan disetiap pertemuan baik pada siklus I dan siklus II yang berfungsi untuk melihat sejauh mana peningkatan kemampuan berhitung Pembagian. Tes kemampuan berhitung Pembagian pada siswa diujikan berbentuk tes essay yang terdiri dari 5 soal yang disusun berdasarkan indikator tes.

Tabel 1: Persentase Peningkatan Hasil Tes Kemampuan Berhitung Pembagian

\begin{tabular}{|c|c|c|c|}
\hline $\begin{array}{c}\text { Kategori } \\
\text { Tes }\end{array}$ & $\begin{array}{c}\text { Rata- } \\
\text { rata } \\
\text { Kelas }\end{array}$ & $\begin{array}{c}\text { Jumlah } \\
\text { siswa } \\
\text { yang } \\
\text { Tuntas } \\
\end{array}$ & $\begin{array}{l}\text { Persentase } \\
\text { Ketuntasan }\end{array}$ \\
\hline Pre test & 51,57 & 6 & $31,57 \%$ \\
\hline $\begin{array}{l}\text { Tes } \\
\text { pertemuan } \\
1 \text { siklus I }\end{array}$ & 61,31 & 9 & $47,36 \%$ \\
\hline $\begin{array}{l}\text { Tes } \\
\text { pertemuan } \\
2 \text { siklus I }\end{array}$ & 66,67 & 15 & $61,90 \%$ \\
\hline $\begin{array}{l}\text { Tes } \\
\text { pertemuan } \\
1 \text { siklus II }\end{array}$ & 72,10 & 15 & $73,68 \%$ \\
\hline $\begin{array}{l}\text { Tes } \\
\text { pertemuan } \\
2 \text { siklus II }\end{array}$ & 5,52 & 16 & $78,94 \%$ \\
\hline
\end{tabular}

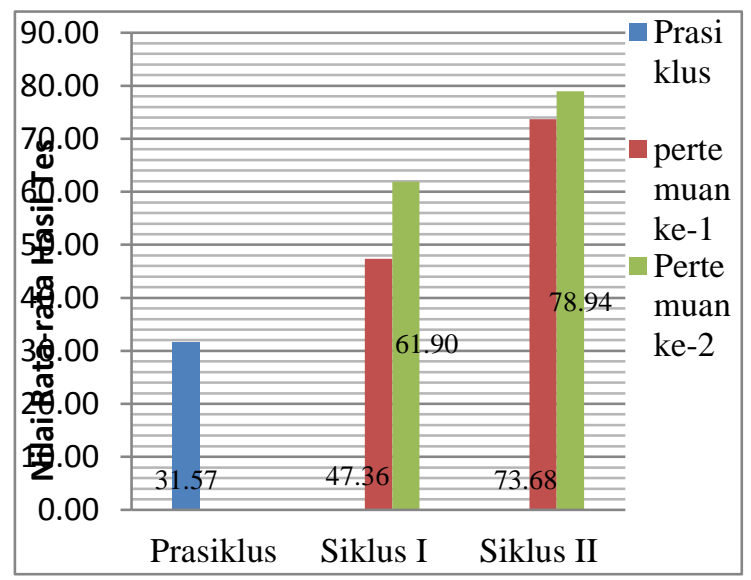

Gambar 1: Diagram Batang Nilai Rata-rata Peningkatan Hasil Tes Kemampuan Berhitung Pembagian

\section{Hasil Observasi}

Tabel 2: Persentase Peningkatan Hasil Observasi Kemampuan Berhitung Pembagian

\begin{tabular}{ccc}
\hline \multicolumn{2}{c}{ Pelaksanaan } & Rata-rata \\
\hline \multirow{2}{*}{ Siklus I } & Pert 1 & $59,99 \%$ \\
\multirow{2}{*}{ Siklus II } & Pert 2 & $69,99 \%$ \\
& Pert 3 & $73,68 \%$ \\
& Pert 4 & $78,98 \%$ \\
\hline
\end{tabular}

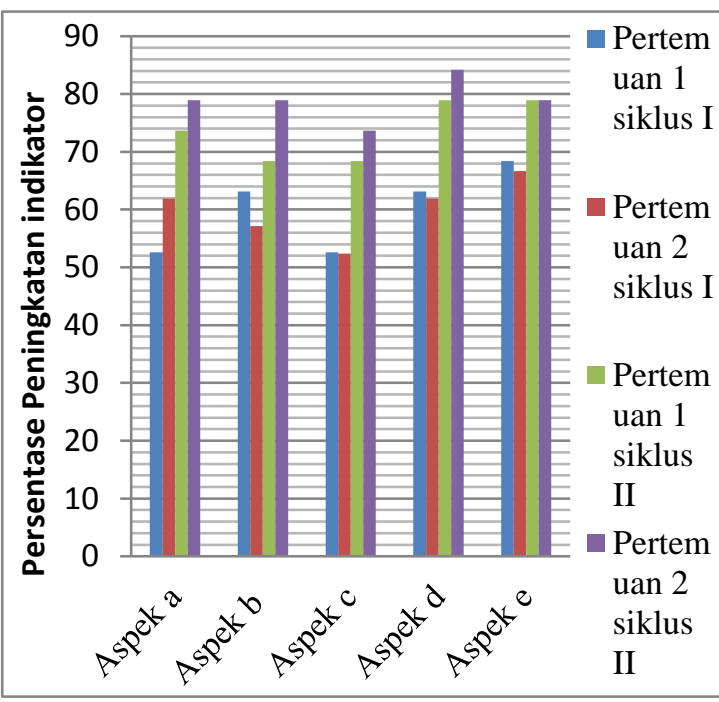

Gambar 2: Diagram Batang Persentase Peningkatan Indikator Kemampuan Berhitung Pembagian Berdasarkan Observasi

Dari hasil penelitian, diperoleh dari siklus I dan siklus II untuk hasil tes dan observasi, menunjukkan bahwa terjadi peningkatan kemampuan berhitung Pembagian pada siswa kelas III SD Negeri 195 Pagaran Baru Kecamatan Kotanopan. Adapun upaya yang dilakukan sehingga terjadi peningkatan kemampuan berhitung Pembagian yaitu dengan menggunakan metode Jarimatika. Berikut ini penjabaran hasil analisis data yang diperoleh: Pada tes awal jumlah siswa yang tuntas 6 siswa dengan persentase ketuntasan $31,57 \%$.

Setelah dilaksanakan penggunaan matode Jarimatika terjadi peningkatan kemampuan berhitung Pembagian pada setiap pertemuan. Pada tes pertemuan ke-1 
siklus I jumlah siswa yang tuntas 9 siswa dengan persentase ketuntasan $47,36 \%$ dan pada tes pertemuan ke-2 siklus I jumlah siswa yang tuntas meningkat menjadi 13 siswa dengan persentase ketuntasan $61,90 \%$. Setelah dilakukan siklus II pada pertemuan ke-1 jumlah siswa yang tuntas 14 siswa dengan persentase ketuntasan $73,68 \%$ dan pada pertemuan ke-2 jumlah siswa yang tuntas meningkat menjadi 15 dengan persentase ketuntasan78,94\%.

Peningkatan nilai rata-rata dari siklus I ke siklus II meningkat dari 52,38\% menjadi $78,94 \%$, terjadi peningkatan sebesar $25,56 \%$. Sedangkan peningkatan pada siklus I pertemuan ke-1 ke pertemuan ke-2 untuk hasil tes siswa sebesar $14,54 \%$ dan peningkatan hasil tes siklus II pertemuan ke-1 ke pertemuan ke-2 meningkat sebesar 5,26\%. Hal tersebut menunjukkan persentase ketuntasan telah mencapai target yang diharapkan yaitu lebih dari $70 \%$. Hasil penelitian tersebut menunjukkan bahwa kemampuan siswa dalam berhitung Pembagian meningkat dengan menggunakan metode Jarimatika.

\section{SIMPULAN}

Berdasarkan hasil penelitian yang telah dilaksanakan dan diuraikan serta dijelaskan sebelumnya, maka dapat disimpulkan bahwa dengan menggunakan metode Jarimatika dapat meningkatkan kemampuan berhitung Pembagian pada siswa kelas III SD Negeri 195 Pagaran Baru Kecamatan Kotanopan dan berada pada kriteria baik.

Pada siklus I adanya peningkatan dari $47,36 \%$ atau 9 siswa menjadi $61,90 \%$ atau 13 siswa dengan peningkatan sebesar $14,54 \%$. Hasil refleksi pada siklus I, untuk memperbaiki kekurangan atau mengatasi masalah-masalah yaitu dengan memberikan hadiah/reward selain itu peneliti juga menyuruh masing-masing kelompok menyiapkan yel-yel yang lucu maupun unik dan memberikan nama kelompok masing-masing dengan nama yang disukai. Pada siklus II terdapat peningkatan dari $73,68 \%$ atau 14 siswa menjadi $78,95 \%$ atau 15 siswa dengan peningkatan sebesar $5,26 \%$.

Hasil refleksi menunjukkan bahwa penggunaan metode Jarimatika dapat meningkatkan kemampuan berhitung Pembagian menjadi lebih mudah dan menyenangkan sesuai dengan target yang diharapkan oleh peneliti dalam penelitian ini, karena pada siklus II target yang telah ditentukan telah tercapai dengan persentase ketuntasan belajar lebih dari $70 \%$, maka penelitian ini diakhiri sampai pada siklus II pertemuan ke-2 dengan peningkatan dari siklus I ke siklus II sebesar 43,36\%.

\section{DAFTAR PUSTAKA}

Abdurrahman, Mulyono. (2012). Anak Berkesulitan Belajar, Jakarta: Rineka Cipta.

Amri, Sofan. (2013) Pengembangan \& Model Pembelajaran dalam Kurikulum, Jakarta: PT Pustakarya. Arikunto, Suharsimi. (2012). Dasar-Dasar Evaluasi Pendidikan, Jakarta: Bumi Aksara.

Aulia M. Fajar. (2008). Berhitung Dashyat dengan Jari Jarimagic, Jakarta: PT Buku Kita.

Hasratuddin. (2015). Mengapa Harus Belajar Matematika, Medan: Perdana Publishing.

Jafar, Muhammad. (2012). Teknik Berhitung Cepat dengan Beragam Variasi Metode Baru Education Arithmetic. Yogyakarta: Wiyata Karya Pustaka.

Kusnadi, Dedi dan Adi Trisno. (2007). Kunci Belajar Menuju Sukses Cermat, Ciamis: Mekar Mandiri.

MM. Endang Susetyawati dan Sumaryanta. 2005. Teknologi Pembelajaran Matematika. Universitas PGRI Yogyakarta. 